\title{
MANAJEMEN PERPUSTAKAAN BERBASIS SISTEM OTOMASI
}

\section{Trifanny Magistra Audia Rahman}

Universitas Islam Negeri Sunan Gunung Djati Bandung

Jl. A.H. Nasution No. 105 Cibiru Bandung

Email: fanijurusanmpi@gmail.com

\section{ABSTRAK}

Tujuan penelitian ini adalah untuk mengetahui latar belakang Perpustakaan Balai Diklat Keagamaan (BDK) Bandung, proses manajemen perpustakaan berbasis sistem otomasinya yang dimulai dari konsep perencanaan, pengorganisasian, pelaksanaan dan pengawasan. Disertai faktor penunjang, faktor penghambat, serta keberhasilan yang dicapai. Penelitian ini menggunakan metode penelitian deskriptif kualitatif dan teknik pengumpulan data melalui wawancara, observasi, dokumentasi dan menyalin. Perencanaan perpustakaan bertujuan supaya perpustakaan bisa melaksanakan kegiatan simpan dan pinjam buku (2) Pengorganisasian meliputi perincian pelaksanaan pekerjaan, pembagian kerja pegawai, mengabungkan pekerjaan para anggota, menetapkan mekanisme kerja, melakukan monitoring, dan rotasi pegawai. (3) Pelaksanaan manajemen perpustakaan berbasis sistem otomasi menggunakan aplikasi E-Office (4) Pengawasan kegiatan perpustakaan, pengawasan hardware dan software, serta pengawasan kinerja pegawai. (5) Faktor penunjangnya kemampuan aplikasi E-Office. Faktor penghambatnya untuk yang internal seperti kendala aplikasi $E$-Office, sedangkan faktor eksternalnya seperti persaingan dengan Badan Litbang lainnya. (6) Keberhasilan manajemen perpustakaan berbasis sistem otomasi adalah dari segi koleksi buku serta manfaat aplikasi E-Office.

Kata Kunci: Manajemen, Perpustakaan, Sistem Otomasi.

\section{ABSTRACT}

The purpose of this study was to find out the background of the Bandung Education Training Center (BDK) Library, the process of library management based on the automation system which starts from the concept of planning, organizing, implementing and controlling. Accompanied by supporting factors, inhibiting factors, and success achieved. This study uses descriptive qualitative research methods and data collection techniques through interviews, observation, documentation and copying. Library planning aims to enable libraries to carry out savings and loan books activities (2) Organizing includes details of the implementation of work, division of work of employees, combining the work of members, establishing work mechanisms, monitoring, and rotating employees. (3) Implementation of automated system-based library management using E-Office applications (4) Monitoring library activities, 
monitoring hardware and software, and monitoring employee performance. (5) The supporting factor for the ability of an E-Office application. The inhibiting factors for internal ones are constraints on E-Office applications, while external factors are like competition from other $R \& D$ Agencies. (6) The success of library management based on automation systems is in terms of book collections and the benefits of E-Office applications.

Keywords: Management, Library, Automation System.

\section{PENDAHULUAN}

Pendidikan akan selalu menjadi kebutuhan manusia dalam menjalankan kehidupannya. Untuk bisa meningkatkan kualitas pendidikan, maka diperlukan perpustakaan yang berkualitas sebagai salah satu penunjang proses pendidikan. Perpustakaan sejatinya merupakan sarana yang menyediakan bahan pustaka yang diperlukan oleh pengguna jasa layanan perpustakaan, baik itu dalam bentuk berupa buku-buku maupun bukan buku. Di sana pengguna perpustakaan dapat memperoleh informasi dari bahan pustaka dengan cara membaca, mengamati, mendengar, dan sekaligus tempat petugas mengelola perpustakaan (Barnawi dan M. Arifin, 2012:109).

Para era globalisasi ini, perpustakaan-perpustakaan di Indonesia dituntut untuk dapat meningkatkan kualitas dan kuantitas layanannya sehingga dapat memberikan kepuasaan kepada penggunjung perpustakaan. Tak dapat dipungkiri bahwa pada saat ini, perpustakaan mengalami penurunan pengunjung karena masih melekatnya paradigma lama di dalam masyarakat tentang perpustakaan dengan berbagai kerumitannya, seperti keanggotaan, kebijakan, dan kesulitan mencari buku yang dibutuhkan di antara banyaknya jumlah buku di perpustakaan. Sehubungan dengan hal tersebut, maka perlu dilakukannya perubahan dalam kegiatan pengelolaan perpustakaan. Salah satu cara yang bisa digunakan adalah dengan menerapkan teknologi komputer dalam pengelolaan kegiatan perpustakaan.

Saat ini komputer dapat digunakan untuk mempercepat pekerjaan administratif di perpustakaan. Dengan begitu akan lebih efektif dan efisien baik secara waktu, tenaga, pekerjaan dan modal. Sistem pengelolaan perpustakaan seperti ini dikenal dengan sebutan sistem otomasi perpustakaan (library automation system) atau perpustakaan terotomasi. Perpustakaan terotomasi, yaitu perpustakaan yang dalam pengelolaannya sudah menggunakan teknologi komputer. Sistem otomasi ini identik dengan program atau software yang biasa dikenal dengan software otomasi perpustakaan (Supriyanto dan Muhsin, 2012:18).

\section{KAJIAN TEORI}

Stoner dalam buku Manajemen Pendidikan yang disusun oleh Tim Dosen Administrasi Pendidikan Universitas Pendidikan Indonesia (2015:86) manajemen merupakan proses perencanaan, pengorganisasian, pengarahan dan pengawasan usaha-usaha para anggota organisasi dan penggunaan sumber daya organisasi lainnya agar mencapai tujuan yang telah ditetapkan. Masih di dalam buku yang sama, menurut Hersey dan Blanchard (2015:86) manajemen merupakan suatu proses bagaimana pencapaian sasaran organisasi melalui kepemimpinan. Sedangkan, menurut Sudjana (2015:87) 
manajemen merupakan rangkaian berbagai kegiatan wajar yang dilakukan seseorang berdasarkan norma-norma yang telah ditetapkan dan dalam pelaksanaannya memiliki hubungan dan saling keterkaitan dengan lainnya.

Dengan demikian dapat disimpulkan bahwa yang dimaksud dengan manajemen adalah kemampuan dan keterampilan proses pengelolaan kegiatan secara perorangan ataupun bersama orang lain dalam upaya mencapai tujuan yang telah ditetapkan. Manajemen dilakukan supaya pelaksanaan suatu usaha terencana secara sistematis dan dapat dievaluasi secara benar, akurat dan lengkap sehingga mencapai tujuan secara produktif, berkualitas, efektif, dan efisien.

Selanjutnya yang perlu dipahami adalah tentang otomasi perpustakaan. Secara sederhana, otomasi perpustakaan adalah sebuah proses pengelolaan perpustakaan dengan bantuan teknologi informasi (TI) (Miyarso Dwi Ajie, 2009:4). Definisi lebih rinci disampaikan oleh Pendit dalam tulisan yang dituliskan oleh Sri Wahyuni (2016:1) mendefinisikan sistem otomasi perpustakaan adalah seperangkat aplikasi komputer untuk kegiatan di perpustakaan terutama bercirikan penggunaan pangkalan data ukuran besar, dengan kandungan cantuman tekstual dan dengan fasilitas utama dalam hal menyimpan, menemukan, dan menyajikan informasi. Otomasi Perpustakaan (library automation) sebenarnya merupakan proses atau hasil penciptaan mesin swatindak atau swakendali dalam proses tersebut. Penerapannya sebenarnya lebih tepat apabila disebut dengan teknologi informasi. Yaitu, teknologi elektronik yang digunakan untuk pengumpulan, penyimpanan, pengolahan, dan pemanfaatan informasi. Dalam hal ini, tidak hanya terbatas pada pemanfaatan perangkat lunak maupun keras, tetapi juga melibatkan unsur manusia (Andi Prastowo, 2012: 391).

Dari pengertian-pengertian yang telah dibahas sebelumnya, maka dapat ditarik kesimpulan bahwa yang dimaksud Manajemen Perpustakaan Berbasis Sistem Otomasi adalah proses pengelolaan segala kegiatan yang berhubungan dengan penyelenggaraan perpustakaan menggunakan bantuan teknologi informasi (TI) beserta komponen-komponennya secara terpadu, sehingga dapat mencapai tujuan perpustakaan secara produktif, efektif, dan efisien. Bidang pekerjaan perpustakaan yang dapat diintegrasikan dengan sistem otomasi perpustakaan, yaitu: Pengadaan Koleksi Bahan Pustaka, Inventarisasi, Klasifikasi, Katalogisasi, Layanan Sirkulasi, Pengelolaan terbitan berkala, dan Pengelolaan Anggota (Supriyanto dan Muhsin, 2012:33). Di mana dalam prosesnya tidak akan lepas dari fungsi-fungsi manajemen, yaitu: planning (perencanaan), organizing (pengorganisasian), actuating (pelaksanaan), dan controlling (pengawasan). Lebih umumnya fungsi-fungsi manajemen ini dikenal dengan sebutan POAC.

Perencanaan (Planning) adalah proses memikirkan dan menetapkan kegiatan-kegiatan atau program-program yang akan dilakukan pada masa yang akan datang untuk mencapai tujuan tertentu (Sagala, 2013:56). Pengorganisasian (Organizing) merupakan penentuan pekerjaan-pekerjaan yang harus dilakukan, pengelompokkan tugas-tugas dan membagi-bagikan pekerjaan kepada setiap karyawan, penetapan departemen-departemen (sub sistem) serta penentuan hubungan-hubungan (Badrudin, 2013:111). Pelaksanaan (Actuating) merupakan tahapan realisasi rencana yang telah 
disusun sebelumnya dengan mengacu pada pengorganisasian (A. Rusdiana dan Irfan, 2014:116). Sedangkan, pengawasan (Controlling) adalah proses pemantauan, penilaian, dan pelaporan rencana atas pencapaian tujuan yang telah ditetapkan untuk tindakan korektif guna penyempurnaan lebih lanjut (Andi Prastowo, 2012:36).

Agar manajemen perpustakaan berbasis sistem otomasi meraih keberhasilan, maka pihak manajemen perlu mengenali faktor-faktor kekuatan, kelemahan, peluang yang mungkin atau diperkirakan akan timbul, dan berbagai ancaman yang harus dihadapi. Caranya adalah dengan melakukan analisis SWOT. SWOT adalah singkatan dari Strenghts, Weakness, Opportunities and Threats (Kekuatan, Kelemahan, Peluang dan Ancaman). Di mana kekuatan dan kelemahan merupakan faktor internal. Sedangkan peluang dan ancaman merupakan faktor eksternal (Sagala, 2013:140-141).

Hasil yang paling diharapkan dengan diterapkannya sistem otomasi dalam kegiatan manajemen perpustakaan adalah meningkatnya mutu pelayanan perpustakaan karena adanya pekerjaan-pekerjaan yang bersifat rutin cenderung diambil alih oleh komputer, sehingga pustakawan dapat menggunakan waktu lebihnya untuk mengurusi pengembangan perpustakaan (Fahmi, 2013:22). Indikator-indikator yang dapat dijadikan pedoman menjadi manajemen perpustakaan yang berhasil dengan memanfaatkan bantuan software otomasi, di antaranya adalah: (1) Tata cara pelayanan perpustakaan menjadi lebih sederhana, mudah, aman, dan singkat dengan menggunakan bantuan komputer. (2) Pengguna bisa mengetahui seluruh informasi yang mereka butuhkan secara terbuka, jelas, dan pasti. (3) Tugas-tugas kegiatan perpustakaan dapat dikerjakan secara cepat, tepat, dan lebih menyenangkan oleh petugas perpustakaan disebabkan pekerjaan-pekerjaan yang menjemukan dapat dialihkan ke peralatan teknologi informasi. (4) Terjadinya penghematan biaya di berbagai bidang. (5) Pihak perpustakaan dapat melakukan komunikasi berbagai macam pihak tanpa perlu bertemu secara langsung.

\section{METODE PENELITIAN}

Penelitian ini menggunakan metode penelitian kualitatif. Penelitian dilakukan di Balai Diklat Keagamaan (BDK) Bandung dan objek penelitiannya adalah Manajemen Perpustakaan Berbasis Sistem Otomasi.

Sumber data meliputi: 1) Kepala Perpustakaan BDK Bandung Bapak Aep Saepudin, S.Ag., 2) Pegawai Bidang Teknologi Informasi Bapak Dindin Firmansyah, ST., dan Bapak Yayat Hidayat, A.Md., 3) Programmer Honorer Bapak Fani Julianto, 4) Pegawai Bidang Pengadaan Bapak Sartono dan Bapak Deni Haryadi, 5) Pegawai Bidang Kepegawaian Bapak Agus Nashiyatul Ahyar, S.Pd.I., 6) Pengelola BMN Bapak Apif Zaelani Sidiq, S.H., 7) Pegawai Perjanjian Ikatan Komitmen Bapak Nana Umar Sumarna, 8) Sekretaris Bidang Jurnal Bapak Dudung Abdul Rohman, M. Ag., 9) Petugas Kebersihan Bapak Wahyu, dan 10) Beberapa orang pegawai selaku pengunjung perpustakaan. Teknik pengumpulan data meliputi: 1) Wawancara, 2) Observasi, 3) Dokumentasi, dan 4) Studi Kepustakaan.

Analisis data dilakukan dengan unitisasi data, kategorisasi data, dan penafsiran data. Adapun uji keabsahan data dilakukan dengan perpanjangan pengamatan, ketekunan pengamatan, triangulasi, pemeriksaan sejawat, 
kecukupan referensi, kajian kasus negatif, pengecekan anggota, uraian rinci, audit kebergantungan, dan audit kepastian.

\section{HASIL DAN PEMBAHASAN \\ Perencanaan}

Kegiatan perencanaan perpustakaan terbagi menjadi tiga, yaitu perencanaan strategis, perencanaan taktis, dan perencanaan operasional. Dalam perencanaan strategis keputusan pimpinan beserta visi dan misi BDK Bandung sebagai pedoman pelaksanaan kegiatan perpustakaan. Perencanaan taktis meliputi hal-hal terkait perbaikan kegiatan pelayanan perpustakaan, seperti mengeluarkan buku-buku yang tidak terpakai, menambah jumlah ekslempar buku-buku perpustakaan, lebih mempernyaman lagi ruangan perpustakaan, dan meningkatkan menu perpustakaan pada aplikasi E-Office. Sedangkan, perencanaan operasional meliputi kegiatan pengudangan bukubuku perpustakaan yang dilaksanakan tiap satu tahun sekali. Tujuan dari kegiatan-kegiatan perencanaan ini adalah supaya perpustakaan bisa melaksanakan kegiatan simpan dan pinjam buku secara maksimal setiap harinya

Kegiatan perencanaan ini didukung beberapa usaha supaya penyelenggaraan kegiatan perpustakaan berjalan secara efektif dan efisien, salah satunya adalah dengan pembuatan tata tertib perpustakaan. Tata tertib perpustakaan BDK Bandung dibuat oleh Bidang Perpustakaan dengan persetujuan dari Pimpinan, di antaranya adalah: 1) Setiap pengunjung yang mengunjungi perpustakaan harus mengisi daftar pengunjung dan bagi yang meminjam buku harus mengisi daftar peminjam, 2) Pengunjung boleh membaca buku apa saja di perpustakaan, akan tetapi tidak boleh dibawa keluar perpustakaan tanpa izin, 3) Yang boleh meminjam buku-buku perpustakaan adalah Pimpinan, Widyaiswara, dan Pegawai BDK Bandung. Selain itu tidak boleh kecuali dengan persyaratan tertentu, 4) Pengunjung dilarang mencoret, merobek, atau merusak buku-buku di perpustakaan.

Supaya aplikasi E-Office dapat memenuhi kebutuhan pegawai perpustakaan, maka perlu dilakukan perencanaan terkait pengembangan aplikasi E-Office yang dilakukan oleh Bidang Teknologi Informasi dengan langkah-langkah berupa mengumpulkan data, melakukan analisis sistem, membuat konten tambahan aplikasi, testing, dan evaluasi konten.

\section{Pengorganisasian}

Dalam pengorganisasian pegawai, BDK Bandung menempatkan Bidang Perpustakaan bersama Bidang Teknologi Informasi sebagai Jabatan Fungsional Umum (JFU) dan berada di bawah Kepala Sub Bagian (Kasubag) Tata Usaha. Hal ini dilakukan supaya baik Bidang Perpustakaan maupun Bidang Teknologi Informasi tetap dapat menyampaikan suatu perihal terhadap pimpinan melalui Kasubag TU, sehingga memudahkan pimpinan dalam pengambilan keputusan.

Penempatan pegawai untuk bekerja di bidang yang mana ditentukan oleh pimpinan. Untuk saat ini, pegawai perpustakaan di BDK Bandung hanya ditangani oleh Pak Aep Saepudin. Sedangkan, pegawai di Bidang Teknologi Informasi yang berperan sebagai petugas sistem otomasi perpustakaan ditangani oleh dua orang, yaitu Pak Dindin Firmansyah dan Pak Yayat Hidayat. 
Pembagian kerja pegawai di Bidang Perpustakaan maupun Bidang Teknologi Informasi sudah ditentukan dalam SKP yang sudah dibuat.

Tugas pegawai yang ditempatkan di Bidang Perpustakaan berdasarkan SKP di antaranya adalah: 1) Mencatat Pengunjung dan Peminjam Perpustakaan, 2) Mencatat Keluar - Masuk Buku Perpustakaan, 3) Mengklasifikasi Buku Baru/ Lama Perpustakaan, 4) Mel-Label / Membarcode Buku Baru / Lama Perpustakaan, dan 5) Menyimpan Data Buku Baru / Buku Lama pada Katalog Aplikasi E-Office.

Sedangkan, tugas pegawai yang ditempatkan di Bidang Teknologi Informasi berdasarkan SKP di antaranya adalah: 1) Mengelola Server dan Backup Database Simdiklat dan E-Office, 2) Mengelola atau mengembangkan perangkat keras (hardware), 3) Mengelola atau mengembangkan perangkat lunak (software), 4) Mengelola atau mengembangkan jaringan komputer dan internet, dan 5) Pengelolaan dan Pengembangan Aplikasi Simdiklat dengan konsultan.

Disebabkan Bidang Perpustakaan dan Bidang Teknologi Informasi posisinya berada di bawah Kasubag TU, maka kegiatan monitoring langsung dilakukan oleh Kasubag TU dan hasilnya dilaporkan ke pimpinan. Walaupun tidak dilakukan secara rutin karena dalam pelaksanaannya tidak ada peraturan yang mengikat.

Pegawai di BDK Bandung mengikuti berbagai macam workshop untuk meningkatkan kemampuannya dan pemberian hukuman disiplin kepada pegawainya yang melanggar sebagai bentuk menjaga moral kerja pegawai.

Untuk menjaga supaya struktur organisasi di BDK Bandung selalu efektif, BDK Bandung mengadakan restrukturasi organisasi yang bentuknya berupa rotasi pegawai. Rotasi untuk pegawai seperti Bidang Perpustakaan maupun Bidang Teknologi Informasi dilakukan sesuai kebutuhan, sedangkan untuk pimpinan berdasarkan kebijakan dari Badan Litbang.

Sampai saat ini Bidang Teknologi Informasi belum mengalami rotasi pegawai. Sedangkan, untuk Bidang Perpustakaan sudah mengalami beberapa kali rotasi pegawai di mana rotasi pegawai yang terakhir kali dilakukan pada tahun 2017, yaitu pegawai Bidang Perpustakaan yang mulanya berjumlah dua orang menjadi hanya Pak Aep Saepudin disebabkan Pak Asep Mutaqin sudah pensiun pada tahun ini.

\section{Pelaksanaan}

Jenis-jenis kegiatan perpustakaan berbasis sistem otomasi meliputi pengadaan, invetarisasi, klasifikasi, layanan sirkulasi, pengelolaan terbitan berkala, dan pengelolaan anggota. Kegiatan pengadaan perpustakaan berbasis sistem otomasi di BDK Bandung terbagi menjadi tiga jenis, yaitu pengadaan bahan pustaka, hardware, dan software. Tiap kegiatan melibatkan aplikasi $E$ Office di dalamnya. Aplikasi E-Office adalah sebuah aplikasi yang murni dirancang dan dibuat oleh BDK Bandung yang dapat mengakomodir seluruh Bidang di BDK Bandung, sehingga dapat mempermudah dan memperlancar pekerjaan pegawai termasuk pekerjaan layanan perpustakaan.

Proses kegiatan pengadaan secara umum terdiri dari mengidentifikasi kebutuhan, permintaan persetujuan kepada KPA (Kuasa Pengguna Anggaran), pembuatan pagu anggaran, penyusunan Harga Penawaran Sendiri (HPS) dan dibandingkan dengan harga penawaran, memilih rekanan dan melakukan 
negosiasi, pembuatan Surat Perintah Kerja (SPK) dan Surat Perintah Mulai Kerja (SPMK) kepada rekanan yang dipilih, pemeriksaan barang dan jasa, serta pembuatan berita acara.

Proses kegiatan inventarisasi dimulai dengan pemeriksaan kesesuaian buku yang diterima dengan keterangan yang tertera di surat pengantar, pemberian cap, dan memasukkan data buku ke dalam dalam database aplikasi E-Office. Cara mengakses database buku di aplikasi E-Office adalah dengan menekan tab menu Subbag TU> Perpustakaan> Database Buku pada aplikasi E-Office. Kemudian akan muncul jendela menu database buku berikut:

(Gambar 1. Menu Database Buku)

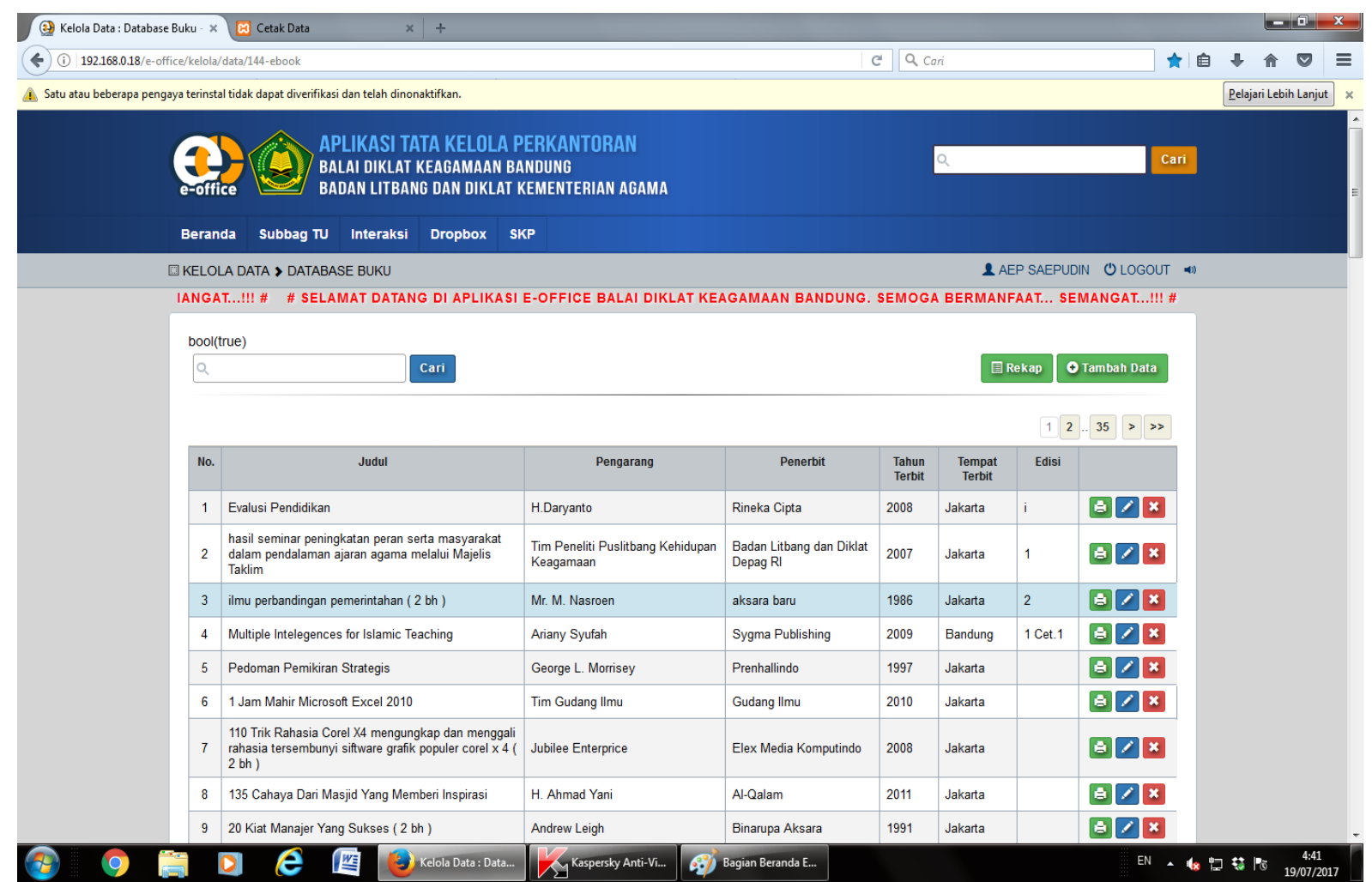

Untuk menambah data buku baru, maka caranya adalah dengan menekan tombol Tambah Data di pojok kanan atas. Pegawai perpustakaan lalu mengisi box-box yang tersedia sesuai dengan keterangan di buku yang diterima.

Pengklasifikasian buku-buku di BDK Bandung menggunakan sistem klasifikasi DDC (Dewey Decimal Classification) dan dalam prosesnya menggunakan freeware e-DDC Edition 23 version 3.3 (Electronic Dewey Decimal Classification) untuk membantu kegiatan pegawai perpustakaan dalam menentukan nomor klasifikasi suatu buku. Layanan Sirkulasi di lingkungan BDK Bandung merupakan layanan terbuka (open access) di mana pengunjung dapat memilih bahan perpustakaan langsung ke rak penyimpanan dan tidak terbatas untuk memanfaatkannya di dalam ruang baca dan diperbolehkan meminjam dibawa ke luar lingkungan BDK Bandung. Pencatatan nama peminjam buku dilakukan secara otomasi menggunakan menu Pinjaman Buku di aplikasi E-Office maupun secara manual dengan pengunjung mengisi sendiri 
daftar peminjam. Perpustakaan di BDK Bandung juga menyediakan Layanan Buku Tandun (book on reserved), scanning, dan printing.

Dalam pengelolaan terbitan berkala, ada beberapa jenis terbitan berkala yang dikelola oleh Perpustakaan BDK Bandung, di antaranya adalah jurnal diklat keagamaan Tatar Pasundan, jurnal dari Badan Litbang dan Pusdiklat yang lain, majalah suara diklat, laporan tahunan, majalah Tempo, majalah Warta, dan koran Pikiran Rakyat. Sedangkan, untuk pengelolaan anggota terkait dengan kegiatan daftar pengunjung dan pembagian file-file tertentu terhadap pengunjung perpustakaan melalui menu Dropbox dalam aplikasi $E$ Office.

\section{Pengawasan}

Kegiatan pengawasan yang diteliti di BDK Bandung meliputi pengawasan kegiatan perpustakaan, pengawasan hardware dan software, serta pengawasan kinerja pegawai. Pengawasan kegiatan perpustakaan dilakukan oleh pegawai perpustakaan. Hal-hal yang diawasi adalah kegiatan pengunjung perpustakaan, koleksi bahan pustaka (sirkulasi), lingkungan, dan kondisi sarana prasarana perpustakaan (fisik). Selama melaksanakan kegiatan pengawasan, pegawai perpustakaan menilai bahwa pengunjung perpustakaan kadang-kadang mengikuti dan kadang-kadang tidak mengikuti tata tertib perpustakaan.

Pengawasan terkait hardware dan software aplikasi E-Office dilakukan oleh Bidang Teknologi Informasi dengan cara melakukan pengecekan kepada beberapa divisi terkait masalah hardware maupun software.

Sedangkan, kegiatan pengawasan kinerja pegawai dilakukan secara langsung maupun tidak langsung oleh pihak atasan. Secara langsung, pengawasan dilakukan oleh Kasubag TU. Pengawasan secara tidak langsung dilakukan oleh Kepala BDK Bandung dengan dua cara, yaitu dengan mengecek langsung aplikasi E-Office pada menu Absensi dan laporan dari pegawai yang terdiri dari LKH (Laporan Kerja Harian) dan SKP Tahunan.

Berdasarkan hasil pengawasan yang dilakukan terhadap pegawai BDK Bandung yang bertanggung jawab terhadap manajemen perpustakaan berbasis sistem otomasi selama setahun terakhir para pegawai dianggap sudah melakukan kegiatan sesuai dengan standar setelah dibandingkan dengan pelaksanaan kegiatan nyata. Alasannya karena baik pegawai di Bidang Perpustakaan dan Bidang Teknologi Informasi sudah tertib hadir dalam setiap waktu kerja, tidak melakukan tindakan yang melanggar aturan, melakukan pekerjaan sesuai SKP dan sudah maksimal melakukan tugasnya berdasarkan kemampuannya masing-masing.

\section{Faktor Penunjang}

Faktor penunjang dalam manajemen perpustakaan berbasis sistem otomasi di BDK Bandung, yaitu pengguna yang mendukung pelaksanaan manajemen perpustakaan berbasis sistem otomasi, fasilitas gedung dan sarana pendukung yang menunjang keberhasilan pelayanan perpustakaan berbasis sistem otomasi, kemampuan aplikasi E-Office, koleksi bahan pustaka, inovasi pegawai perpustakaan, motivasi membaca, kepemimpinan, kebijakan pemerintah di bidang perpustakaan, dan kemudahan untuk memperoleh bukubuku perpustakaan dan produk teknologi informasi. 


\section{Faktor Penghambat}

Faktor penghambat dalam manajemen perpustakaan berbasis sistem otomasi di BDK Bandung, yaitu adalah tidak sempurnanya database buku, kurangnya pengetahuan pegawai perpustakaan tentang masalah perpustakaan, minat membaca pengunjung yang rendah, kendala aplikasi E-Office, kebiasaan buruk pengunjung perpustakaan, tingkat kesibukan, keterbatasan anggaran, dan persaingan dengan badan litbang yang lain.

\section{Keberhasilan yang Diperoleh}

Keberhasilan dari manajemen perpustakaan berbasis sistem otomasi di BDK Bandung adalah tercapainya tujuan yang telah ditetapkan, yaitu menyediakan koleksi bahan pustaka yang dapat menunjang kegiatan kediklatan dan penelitian yang dibuktikan dengan jumlah koleksi secara keseluruhan berjumlah 10.500 ekslempar. Koleksi-koleksi tersebut lalu dapat dibedakan menjadi sebagai berikut:

1. Koleksi Utama

Koleksi buku-buku perpustakaan berjumlah 2749 judul buku dengan jumlah ekslempar sebanyak 5475 buah, yang rinciannya adalah sebagai berikut:

\begin{tabular}{|c|l|c|c|}
\hline \multirow{2}{*}{ No } & \multicolumn{1}{|c|}{ Jenis Koleksi } & \multicolumn{2}{|c|}{ Jumlah } \\
\cline { 3 - 4 } & Kudul & Ekslempar \\
\hline 1 & Karya Umum & 45 & 74 \\
\hline 2 & Filsafat dan Psikologi & 48 & 113 \\
\hline 3 & Agama & 1077 & 1920 \\
\hline 4 & Ilmu-ilmu Sosial & 654 & 1240 \\
\hline 5 & Bahasa & 47 & 87 \\
\hline 6 & Ilmu-ilmu alam dan matematika & 308 & 670 \\
\hline 7 & Teknologi dan ilmu-ilmu terapan & 467 & 1223 \\
\hline 8 & Kesenian, Hiburan, dan Olahraga & 13 & 17 \\
\hline 9 & Kesusastraan & 64 & 86 \\
\hline 10 & Geografi dan Sejarah & 26 & 45 \\
\hline & Jumlah & $\mathbf{2 7 4 9}$ & $\mathbf{5 4 7 5}$ \\
\hline
\end{tabular}

(Tabel 1. Kolesksi Utama Perpustakaan BDK Bandung)

2. Koleksi Pendukung

Koleksi yang merupakan koleksi buku titipan dan buku-buku produk kediklatan. Rinciannya adalah sebagai berikut:

\begin{tabular}{|c|l|c|}
\hline No & \multicolumn{1}{|c|}{ Jenis Produk } & Jumlah \\
\hline 1 & Modul & 1442 \\
\hline 2 & Jurnal kompetensi & 650 \\
\hline 3 & Pedoman Diklat & 1723 \\
\hline 4 & Kurikulum dan Silabus & 364 \\
\hline 5 & Majalah Suara Diklat & 532 \\
\hline 6 & Laporan Tahunan & 144 \\
\hline 7 & Laporan Penelitian & 1048 \\
\hline 8 & Majalah Biasa & 130 \\
\hline & Jumlah & $\mathbf{4 8 5 5}$ \\
\hline
\end{tabular}

(Tabel 2. Koleksi Pendukung Perpustakaan BDK Bandung) 
Selain dilihat dari koleksi perpustakaan, tingkat keberhasilan yang dicapai dalam pelaksanaan manajemen perpustakaan berbasis sistem otomasi di BDK Bandung adalah berdasarkan manfaat yang dirasakan baik oleh pegawai perpustakaan maupun pengunjung perpustakaan dengan digunakannya aplikasi E-Office. Bagi pegawai perpustakaan manfaat aplikasi $E$ Office adalah sebagai berikut:

1. Mudah digunakan karena Layout aplikasi E-Office yang hampir mirip membuat penggunaannya tidak berbelit-belit.

2. Keamanan penggunaannya terjamin sebab selain pegawai tidak ada yang bisa mengakses aplikasi E-Office tanpa menggunakan access log in.

3. Pegawai perpustakaan merasa pekerjaan yang dilakukannya terasa lebih menyenangkan disebabkan pekerjaan-pekerjaan yang sifatnya berulangulang dapat dengan cepat dan tepat dikerjakan dengan bantuan komputer.

4. Pengeluaran biaya perpustakaan menjadi lebih ekonomis karena tidak perlu adanya pengeluaran biaya untuk sarana dan prasarana perpustakaan yang tidak diperlukan, seperti biaya kertas.

5. Bidang Perpustakaan dapat menjalin komunikasi yang baik dengan pengunjung perpustakaan dengan menggunakan menu Chatting dan Forum Diskusi di aplikasi E-Office tanpa perlu bertemu langsung.

6. Dengan digunakannya aplikasi E-Office dalam pelayanan perpustakaan, data buku perpustakaan dapat dikelola secara rapih, terstruktur, dan akuntabel. Hal ini membuat mutunya lebih bagus bila dibandingkan dengan cara manual.

Adapun, bagi pengunjung perpustakaan manfaat aplikasi E-Office adalah sebagai berikut:

1. Database buku perpustakaan di aplikasi E-Office dapat dilihat oleh seluruh pegawai di BDK Bandung secara terbuka, jelas, dan akurat sehingga membuat penggunjung perpustakaan dapat memeriksa terlebih dahulu tentang keberadaan judul buku yang ingin dipinjam sebelum mencarinya di rak perpustakaan.

2. Database buku bisa diunduh oleh pengunjung perpustakaan jika diperlukan secara bebas.

3. Layanan sirkulasi dapat dilaksanakan dengan cepat karena telah disediakan menu daftar pengunjung, pinjaman buku, dan pengembalian buku.

\section{SIMPULAN}

Berdasarkan penelitian di Balai Diklat Keagamaan (BDK) Bandung dalam melaksanakan manajemen perpustakaan berbasis sistem otomasi dapat diperoleh kesimpulan bahwa: (1) Perencanaan perpustakaan bertujuan supaya perpustakaan bisa melaksanakan kegiatan simpan dan pinjam buku secara maksimal setiap harinya. (2) Pengorganisasian meliputi perincian pelaksanaan pekerjaan, pembagian kerja pegawai, mengabungkan pekerjaan para anggota, menetapkan mekanisme kerja, melakukan monitoring, dan rotasi pegawai. (3) Pelaksanaan manajemen perpustakaan berbasis sistem otomasi menggunakan aplikasi E-Office dan juga dilakukan secara manual. (4) Kegiatan pengawasan meliputi pengawasan kegiatan perpustakaan, pengawasan hardware dan software, serta pengawasan kinerja pegawai. (5) Faktor penunjangnya untuk yang internal seperti kemampuan aplikasi E-Office, sedangkan faktor yang 
eksternal seperti kebijakan pemerintah. Adapun faktor penghambatnya untuk yang internal seperti kendala aplikasi E-Office, sedangkan faktor eksternalnya seperti persaingan dengan Badan Litbang yang lain. (6) Keberhasilan manajemen perpustakaan berbasis sistem otomasi adalah dari segi koleksi buku serta manfaat aplikasi E-Office.

Tindakan pegawai perpustakaan menggunakan aplikasi E-Office dan perilaku pengunjung di perpustakaan memberikan gambaran kalau setidaknya manfaat aplikasi E-Office di perpustakaan secara keseluruhan dirasakan oleh pegawai perpustakaan, yaitu membuat kegiatan perpustakaan jadi lebih mudah, cepat, tepat, terbuka, aman, ekonomis, komunikasi yang baik, dan meningkatkan mutu layanan perpustakaan. Manfaat aplikasi E-Office belum sepenuhnya dirasakan oleh pengunjung perpustakaan selain untuk memastikan ketersediaan buku yang mereka cari alasannya karena pengunjung perpustakaan masih harus menuliskan nama mereka di daftar pengunjung dan peminjam perpustakaan secara manual. Oleh karena itu, pegawai perpustakaan harus lebih mendayagunakan kemampuan aplikasi E-Office untuk pengunjung perpustakaan supaya manfaatnya dapat lebih dirasakan lagi oleh pengunjung perpustakaan.

Terlepas dari kekurangan yang dimiliki oleh aplikasi E-Office, tak dapat dipungkiri bahwa dengan penerapan sistem otomasi dalam manajemen perpustakaan di BDK Bandung membuat kegiatan pelayanan perpustakaan mengalami peningkatan dibandingkan sebelumnya, yaitu menjadi lebih efektif dan efisien.

\section{REFERENSI}

Ajie, Miyarso Dwi. (2009). Sistem Otomasi Perpustakaan: Sebuah Pengantar. Handout 1 pada Perkuliahan UPI. Bandung: Universitas Pendidikan Indonesia.

Badrudin. (2013). Dasar-dasar Manajemen. Bandung: Alfabeta.

Barnawi dan M. Arifin. (2012). Manajemen Sarana dan Prasarana Sekolah. Jogjakarta: Ar-Ruzz Media.

Fahmi, Yusri. (2013). Teknologi Informasi dan Automasi Perpustakaan: Kajian pada Perpustakaan di Ethiopia dan India. Jurnal Iqra'. Vol. 7. No. 1. 20-29.

Prastowo, Andi. (2012). Manajemen Perpustakaan Sekolah Profesional. Jogjakarta: DIVA Press.

Rusdiana, A dan Moch. Irfan. (2014). Sistem Informasi Manajemen. Bandung: CV Pustaka Setia.

Sagala, Syaiful. (2013). Manajemen Strategik. Bandung: Alfabeta.

Supriyanto, Wahyu dan Ahmad Muhsin. (2008). Teknologi Informasi Perpustakaan: Strategi Perancangan Perpustakaan Digital. Yogyakarta: Kanisius.

Tim Dosen Administrasi Pendidikan Universitas Pendidikan Indonesia. 2015. Manajemen Pendidikan. Bandung: Alfabeta.

Wahyuni, Sri. (2016). Otomasi Perpustakaan: Alasan Otomasi dan Kontribusi Bagi Perpustakaan. Yogyakarta: STMIK AKAKOM. 